\title{
STUDY OF THE CLINNICAL CHARACTERISTICS AND OUTCOMES OF EXUDATIVE PLEURAL EFFUSION: IMPROVING CLINICAL DECISION MAKING IN RESOURCE LIMITED SETTING
}

 \\ ${ }^{1}$ Division of Pulmonary, Critical Care \& Sleep Medicine, Department of Internal Medicine, B. P. Koirala \\ Institute of Health Sciences, Dharan, Nepal \\ ${ }^{2}$ Department of Pathology, B. P. Koirala Institute of Health Sciences, Dharan, Nepal
}

\section{ABSTRACT}

Introduction: In the background of resource limited setting like Nepal, we set out to identify if specific clinical characteristics and basic lab parameters would guide differentiation of Tuberculous from other causes of exudative pleural effusion.

Methodology: Retrospective study of 109 consecutive patients with exudative pleural effusion.

Results: Compared to Tubercular pleural effusions (41.3\%), increased age, increased duration of symptom and increased pack years statistically favoured a diagnosis of Malignant pleural effusion(21.1\%), whereas presence of fever, cough and increased pleural ADA levels favoured Tubercular pleural effusions. With regards to Parapneumonic effusions (26.6\%), a shorter duration of symptom, smaller effusions, higher pleural Neutrophils, lower pleural lymphocyte neutrophil ratio and lower ADA favoured the diagnosis as compared to Tubercular pleural effusions.

Conclusions: The appreciation of important clinical and pleural biochemical differences between Tubercular and other major causes of exudative pleural effusions aids in improved clinical decision making with minimal resources in resource limited settings like ours.

Key words: Exudative Pleural Effusion, Tuberculosis, Clinical Decision Making

\section{INTRODUCTION}

Pleural effusion is a common presentation in the patients presenting to the Pulmonologists. The etiology of Pleural Effusion depends on geographic region, patient characteristics, and the availability of diagnostic facilities in that region. Pleural effusions can be transudative or exudative., ${ }^{1,2}$ In cases with transudative pleural effusion the diagnosis is usually made without much difficulties but exudative pleural effusion requires careful differential diagnosis that includes parapneumonic effusion, tuberculosis, and metastatic cancers which are found to be the cases in large number

\footnotetext{
Correspondence:

Dr. Deebya Raj Mishra

Senior Resident (D.M.)

Division of Pulmonary, Critical Care \& Sleep Medicine Department of Internal Medicine

B.P. Koirala Institute of Health Sciences, Dharan, Nepal

E-mail: deebya.mishra@bpkihs.edu
}

of patients. ${ }^{3-5}$ Tuberculosis is the most common cause of exudative pleural effusion in many areas of the world. ${ }^{6,7}$ In Nepal, Tuberculosis (TB) is a major public health problem. About 45 percent of the total population is infected with TB, of which 60 percent are adult. Every year, 45, 000 people develop active TB, out of them 20,580 have infectious pulmonary disease. These 20,000 are able to spread the disease to others ${ }^{8}$. Although pulmonary disease is the most common form of TB, extra-pulmonary TB affecting mainly the lymph nodes and pleura serves as the initial presentation in about $25 \%$ of adults. Pleural TB accounts for $4 \%$ of all TB cases in the United States ${ }^{9}$; in Spain, however, this percentage is greater than $10 \% .{ }^{10}$ TB is one of the most common causes of pleural effusion in some geographical areas. ${ }^{11}$ But in the developed world like United States, the leading etiologies of pleural effusion in adults who undergo thoracentesis are CHF, pneumonia, malignancy, pulmonary embolus, viral disease, coronary artery bypass surgery, and cirrhosis with ascites. ${ }^{12}$ Thus it 
becomes very important to understand the clinical characteristics of the causes of Pleural effusion as the treatment, social and economic implications of the diagnosis being Tuberculous or Nontuberculous are tremendous.

\section{METHODOLOGY}

We conducted a retrospective review of the medical records and chest radiographs of consecutive cases of exudative pleural effusions referred to the Respiratory and Internal Medicine services of the $B$ P Koirala Institute of Health Sciences, Nepal during a 15 month period from April 2013 till July 2014. The hospital serves as a referral hospital for the whole of Eastern Nepal. Effusions were classified as exudates when they satisfied Light's criteria ${ }^{13}$ or if frank pus was present.

In the cases with exudative pleural effusion, the relevant data were scanned and included in the study only if the patient chart was viewed as Complete. Complete chart was defined as having detailed epidemiological data, a complete medical history and clinical examination, investigations including Pleural fluid analysis for TC/DC/sugar/ protein/light's criteria, ADA and malignant cytology if diagnosis was inconclusive by routine analysis, other special tests of pleural fluid as required, like, Amylase etc. Only the initial fluid examination was recorded. Once the above parameters were present, the Digital Radiographic Library was explored. The X-Ray was reviewed by a Pulmonology trainee. The size of the effusion was estimated on the initial upright inspiratory posteroanterior chest film. Effusions were classified as; large effusion if effusion covered greater than 50 percent of the hemithorax, medium if 25 to 50 percent was covered, and small effusion if effusion covered less than 25 percent of the hemithorax. The patient's with the following features were classified as Tuberculous pleural effusion.

1. Positive mycobacterial culture in pleural fluid or pleural biopsy tissue samples.

2. Granulomatous inflammation in pleural biopsy tissue samples.

3. Positive AFB stain or mycobacterial culture of sputum sample.

4. Clinically suspected tuberculous pleurisy and pleural effusion that were resolved with antiTB treatment. Here, 'clinical suspicion' means that these patients had no systemic diseases, and were excluded from malignancy and other pleural diseases. Moreover, there were suggestive clues of TB from contact history, radiographical findings or clinical presentation.

5. ADA level of more than 60 with response to anti-TB treatment during hospital stay will also be taken as TB.

All other cases of exudative pleural effusion with complete medical charts were classified as NonTuberculous effusion. These were diagnosed in accordance to the following criteria:

Parapneumonic effusion: Pleural effusion in association with pneumonia, lung abscess, or bronchiectasis.

Empyema: Presence of purulent fluid or positive culture of parapneumonic effusion.

Neoplasia: Neoplastic tissue in the pleural cavity (biopsy and/or cytology) or CT suspicion of malignancy if biopsy and cytology were inaccessible or inconclusive.

Other diagnosis made such as, cirrhosis of the liver, pancreatitis, systemic lupus erythematosus, rheumatoid arthritis, were as per the preestablished criteria. ${ }^{14}$

\section{Statistical analysis}

Data with parametric distribution have been expressed in mean $\pm S D$ and Independent t-test was used for the comparison of variables. Data with non parametric distribution have been expressed as median (25th percentile and 75th percentile) and Mann Whitney test was used for the comparison of variables. The chi-squared analysis was used for comparison of proportions. All statistical test values were two-sided, and a $P$ value of $<0.05$ was considered to be statistically significant. Analysis was carried out using SPSS 17 software.

\section{RESULTS}

Among 109 patients, $58.7 \%$ (64) of the patients were male and the mean age was $47.97( \pm 19.69)$ years. The mean age in patients with Tuberculous pleural effusion (TPE) was $42.3( \pm 18.9)$ years and that in Malignant pleural effusion (MPE) was $65.5( \pm 13.6)$ years. The etiological distribution of the pleural effusions with the number of patients in each etiological group and the mean age of the group are shown in Table 1. $41.3 \%(45)$ of the cases were Tuberculous in origin and there was 1 
case of Hepatitis A associated pleural effusion. The majority of parapneumonic effusions (82.4\%) were small in size whereas $39.1 \%$ of MPE were large; the majority of TPE were Medium in size (57.8\%).

\begin{tabular}{|c|c|c|c|c|}
\hline \multicolumn{5}{|c|}{$\begin{array}{l}\text { Table 1. Causes, gender and age at diagnosis of } \\
\text { pleural effusion }\end{array}$} \\
\hline & $n$ & $\%$ & $\begin{array}{l}\text { Males/ } \\
\text { Females }\end{array}$ & $\begin{array}{l}\text { Age, } \\
\text { yrs* }^{*}\end{array}$ \\
\hline \multicolumn{5}{|c|}{ Tubercular Pleural Effusion } \\
\hline Tuberculosis & 45 & 41.3 & $27 / 18$ & $42.3+18.9$ \\
\hline \multicolumn{5}{|c|}{ Non Tubercular Effusion } \\
\hline $\begin{array}{l}\text { Malignant Pleural } \\
\text { Effusion }\end{array}$ & 23 & 21.1 & $12 / 11$ & $65.5 \pm 13.6$ \\
\hline $\begin{array}{l}\text { U\&C } \\
\text { Parapneumonic } \\
\text { Effusion }\end{array}$ & 17 & 15.6 & $9 / 8$ & $44.1 \pm 17.7$ \\
\hline Empyema & 12 & 11.0 & $11 / 1$ & $40.25 \pm 17.0$ \\
\hline Hydropneumothorax & 5 & 4.5 & $3 / 2$ & $53 \pm 20.7$ \\
\hline $\mathrm{RA}$ & 1 & 0.9 & $0 / 1$ & $81 \pm 0$ \\
\hline SLE & 2 & 1.8 & $1 / 1$ & $41 \pm 2.8$ \\
\hline $\begin{array}{l}\text { Metastatic Pleural } \\
\text { Effusion }\end{array}$ & 3 & 2.8 & $0 / 3$ & $48 \pm 6.2$ \\
\hline Others\# & 1 & 0.9 & $1 / 0$ & $16 \pm 0$ \\
\hline
\end{tabular}

*Mean \pm SD, \# Hepatitis $\mathbf{A}$ associated pleural effusion

The diagnosis of TB was on the basis of high ADA in $68.9 \%$ of the cases (Table 2). The ADA was less than 60 in 10 of TPE and in 4 cases ADA were not done. Comparatively, ADA of more than 60 was present in $5(21.7 \%)$ of MPE cases and in $5(41.7 \%)$ of the cases with Empyema.

\begin{tabular}{|c|c|c|}
\hline Criteria & $n$ & $\%$ \\
\hline High ADA $(>60)$ & 31 & 68.9 \\
\hline Clinical Suspicion & 7 & 15.6 \\
\hline Sputum AFB positive & 5 & 11.1 \\
\hline Gene Xpert positive & 2 & 4.4 \\
\hline
\end{tabular}

On comparing the clinical and demographic characteristics, the subset of patients with MPE compared to TPE (Table 3) had a greater mean age ( $65 \pm 13$ years vs $42 \pm 18$ years), longer duration of symptoms (median duration 60 days vs 30 days), and they had a longer Smoking history in terms of the Pack years (median duration 30 years to 5 years). The subset with TPE had fever predominantly whereas chest pain was more common in the MPE subset.

On comparing the subset of patients with Parapneumonic effusion (PPE) to TPE (Table 3), the duration of symptom was longer in the Tuberculous group (median duration 8 days to 30 days) whereas the duration of hospitalization (median duration 10 days to 6 days) was longer in the PPE subset, also the size of the effusions where Small in this group compared to the TPE group.

\begin{tabular}{|c|c|c|c|c|c|}
\hline Characteristics & $\begin{array}{c}\text { Tubercular } \\
\text { pleural } \\
\text { effusion } \\
(n=45)\end{array}$ & 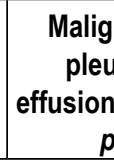 & $\begin{array}{l}\text { Inant } \\
\text { ural } \\
(n=23)\end{array}$ & $\begin{array}{r}\begin{array}{r}\text { Par } \\
\text { pneum } \\
\text { effus } \\
\text { (n=2C }\end{array} \\
\end{array}$ & $\begin{array}{l}\text { a- } \\
\text { nonic } \\
\text { ion } \\
\text { 9)p }\end{array}$ \\
\hline Age (mean (sd)) & $42(18)$ & $65(13)$ & .000 & $42(17)$ & .950 \\
\hline Male $(n(\%))$ & $27(60)$ & $12(52)$ & .537 & $20(69)$ & .434 \\
\hline \begin{tabular}{|l|} 
Duration of \\
Symptom \\
Median \\
(Interquartile \\
Range)
\end{tabular} & $30(15-75)$ & $\begin{array}{l}60 \\
(30-120)\end{array}$ & .049 & $8(4-14)$ & .000 \\
\hline \begin{tabular}{|l|} 
Duration of \\
Hospitalization \\
Median \\
(Interquartile \\
Range) \\
\end{tabular} & $6(4-9)$ & $7(6-8)$ & .172 & \begin{tabular}{|l|}
10 \\
$(7-14.5)$
\end{tabular} & .001 \\
\hline $\begin{array}{l}\text { Shortness of } \\
\text { breath }(n(\%))\end{array}$ & $33(73)$ & $19(82)$ & .394 & 23(79) & .559 \\
\hline Fever (n (\%)) & $33(73)$ & $8(34)$ & .002 & $21(72)$ & .931 \\
\hline Cough $(n(\%))$ & $33(73)$ & $15(65)$ & .487 & $18(62)$ & .307 \\
\hline Sputum $(n(\%))$ & $7(16)$ & $0(0)$ & .046 & 1(4) & .102 \\
\hline Chest Pain $(n(\%))$ & $17(37.8)$ & $15(65)$ & .032 & $10(34)$ & .774 \\
\hline \begin{tabular}{|l} 
Right sided \\
effusion (n (\%))
\end{tabular} & $23(51)$ & $17(73.9)$ & .071 & $19(65)$ & .222 \\
\hline $\begin{array}{l}\text { Large effusion } \\
(n(\%))\end{array}$ & $11(24)$ & $9(39)$ & .209 & $1(3)$ & .017 \\
\hline Smoking $(n(\%))$ & $5(11)$ & 19(82) & .000 & 11(37) & .006 \\
\hline \begin{tabular}{|l|} 
Pack years \\
Median \\
(Interquartile \\
Range)
\end{tabular} & $5(3-7.5)$ & $\begin{array}{l}30 \\
(15-40)\end{array}$ & .001 & $13(5)$ & .008 \\
\hline \begin{tabular}{|l} 
Thoracostomy \\
$(n(\%))$
\end{tabular} & $13(29)$ & $3(13)$ & .145 & $13(44)$ & .161 \\
\hline $\begin{array}{l}\text { Improved } \\
(n(\%))\end{array}$ & $45(100)$ & $0(0)$ & .000 & $28(96)$ & .210 \\
\hline
\end{tabular}

On comparing the pleural fluid characteristics, there was no significant difference in the Pleural fluid TLC, pleural lymphocyte neutrophil ratio, pleural fluid LDH, the LDH ratio and even the pleural fluid protein in the TPE and the MPE group. The pleural fluid ADA was significantly more in the Tubercular group (median value $90 \mathrm{U} / \mathrm{l}$ vs $40 \mathrm{U} / \mathrm{l}$ ) (Table 4). Interestingly, $17(37.8 \%$ ) of the patients with TPE had pleural fluid protein more than 5 in comparison to $1(4.3 \%)$ of MPE and this difference was statistically significant. MPE was diagnosed in these cases on the basis of positive CECT Chest findings in all 23 cases and positive Malignant Cytology results in 9 (39.1\%) of the cases. 
On comparing the subset of patients with PPE to TPE (Table 4), the patients with PPE showed an increased percentage of pleural neutrophils ( median value $85 \%$ vs $30 \%$ ), a decreased percentage of pleural lymphocytes and consequently a lower pleural lymphocyte to neutrophil ratio (median value 0.17 vs 2.33). Pleural fluid ADA levels were significantly higher in the Tubercular group of the patients (median value $90 \mathrm{U} / \mathrm{l}$ to $31 \mathrm{U} / \mathrm{l}$ ). Out of the PPE cases, 12 had empyema and in total 13 patients required thoracostomy.

In the group with TPE, 11(24.4\%) had Large effusions and Steroids had to be added to 9 of these cases.

\begin{tabular}{|c|c|c|c|c|c|}
\hline $\begin{array}{l}\text { Table 4. Cor } \\
\text { tubercular a }\end{array}$ & $\begin{array}{l}\text { nparison o } \\
\text { ld non-tub }\end{array}$ & $\begin{array}{l}\text { ural flui } \\
\text { lar effus }\end{array}$ & & of patients $\mathrm{w}$ & \\
\hline & \begin{tabular}{|l|} 
Tubercular \\
pleural
\end{tabular} & $\begin{array}{l}\text { Malignant } p \\
\text { effusion }(n=\end{array}$ & $\begin{array}{l}\text { leural } \\
\text { 23) }\end{array}$ & $\begin{array}{l}\text { Para-pneumc } \\
\text { effusion }(n=2\end{array}$ & $\begin{array}{l}\text { onic } \\
\text { 9) }\end{array}$ \\
\hline & \begin{tabular}{|l|} 
Median \\
(Interquar- \\
tile Range)
\end{tabular} & \begin{tabular}{|l} 
Median \\
(Interquar- \\
tile Range)
\end{tabular} & $p$ & \begin{tabular}{|l} 
Median \\
(Interquar- \\
tile Range)
\end{tabular} & $p$ \\
\hline $\begin{array}{l}\text { Pleural fluid } \\
\text { TLC per } \\
\text { mm3 }\end{array}$ & \begin{tabular}{|l}
330 \\
$(55-630)$
\end{tabular} & $\begin{array}{l}300 \\
(140-800)\end{array}$ & .645 & \begin{tabular}{|l}
25 \\
$(10-720)$
\end{tabular} & .252 \\
\hline $\begin{array}{l}\text { Pleural neu- } \\
\text { trophils, \% } \\
\end{array}$ & \begin{tabular}{|l|}
30 \\
$(20-70)$ \\
\end{tabular} & \begin{tabular}{|l|}
60 \\
$(20-80)$ \\
\end{tabular} & .297 & \begin{tabular}{|l|}
85 \\
$(67.5-90)$ \\
\end{tabular} & .000 \\
\hline $\begin{array}{l}\text { Pleural lym- } \\
\text { phocytes, \% }\end{array}$ & $\begin{array}{l}70 \\
(30-80)\end{array}$ & $\begin{array}{l}40 \\
(20-80)\end{array}$ & .297 & \begin{tabular}{|l}
15 \\
$(10-32.5)$
\end{tabular} & .000 \\
\hline $\begin{array}{l}\text { Pleural } \\
\text { lymphocyte } \\
\text { neutrophil } \\
\text { ratio }\end{array}$ & \begin{tabular}{|l}
2.33 \\
$(.42-4.00)$
\end{tabular} & \begin{tabular}{|l}
.67 \\
$(.25-2.34)$
\end{tabular} & .096 & $\begin{array}{l}.17 \\
(.11-.47)\end{array}$ & .000 \\
\hline $\begin{array}{l}\text { Pleural } \\
\text { glucose, } \\
\mathrm{mg} / \mathrm{dL}\end{array}$ & \begin{tabular}{|l}
68 \\
$(51.5-101)$
\end{tabular} & \begin{tabular}{|l}
86 \\
$(54-106)$
\end{tabular} & .693 & $\begin{array}{l}21 \\
(11.5-115.5)\end{array}$ & .141 \\
\hline $\begin{array}{l}\text { P/S protein } \\
\text { ratio }\end{array}$ & \begin{tabular}{|l|}
.66 \\
$(.14)^{*}$
\end{tabular} & \begin{tabular}{|l|}
.64 \\
$(.12)^{*}$
\end{tabular} & .694 & \begin{tabular}{|l|}
.63 \\
$(.23)^{*}$
\end{tabular} & .549 \\
\hline $\begin{array}{l}\text { Pleural } \\
\text { Protein } \\
\text { more than } \\
5 \mathrm{~g} / \mathrm{dl}\end{array}$ & \begin{tabular}{|l}
17 \\
$(37.8 \%) \#$
\end{tabular} & $\begin{array}{l}1 \\
(4.3 \%) \#\end{array}$ & .003 & $\begin{array}{l}6 \\
(20.7 \%) \#\end{array}$ & .121 \\
\hline $\begin{array}{l}\text { Pleural LDH, } \\
\text { U/L }\end{array}$ & \begin{tabular}{|l}
520 \\
$(341-693)$ \\
\end{tabular} & \begin{tabular}{|l|}
506.50 \\
$(312-583)$ \\
\end{tabular} & .702 & \begin{tabular}{|l}
420 \\
$(341-738)$ \\
\end{tabular} & .838 \\
\hline $\begin{array}{l}\text { P/S LDH } \\
\text { ratio }\end{array}$ & $\begin{array}{l}1.03 \\
(.85-1.68)\end{array}$ & $\begin{array}{l}1.30 \\
(.85-1.84)\end{array}$ & .466 & $\begin{array}{l}1.26 \\
(1.03-1.92)\end{array}$ & .050 \\
\hline $\begin{array}{l}\text { Pleural ADA, } \\
\text { U/L }\end{array}$ & \begin{tabular}{|l|}
90 \\
$(61-113)$
\end{tabular} & $\begin{array}{l}40 \\
(20-52)\end{array}$ & .000 & \begin{tabular}{|l|}
31 \\
$(24.5-127)$
\end{tabular} & .011 \\
\hline
\end{tabular}

*Mean \pm SD, \#total number(percentage of total)

\section{DISCUSSION}

In a developing country like Nepal, even the tertiary care hospitals have at best ordinary facilities. Though the scenario is gradually changing with
Nepal developing its own specialists and thus the scope of investigations and diagnosis gradually increasing day by day, it is still limited by cost factors and lack of Universal health coverage that is the case in the West. In this background, we tried to focus if differences in clinical and basic lab parameters to differentiate TPE from NTPE would improve clinical decision making.

With regards to the cut off level for ADA, Some large series suggest that a value $>45$ to $60 \mathrm{U} / \mathrm{L}$ is 100 percent sensitive and up to 97 percent specific for TPE. ${ }^{15-19}$ Pleural effusions with an ADA level $<40$ $\mathrm{U} / \mathrm{L}$ are rarely caused by $T B .{ }^{20}$ Since this study was conducted in a resource limited setting, we wanted to increase the Specificity of the diagnosis of TPE and thus used ADA value of more than $60 \mathrm{U} / \mathrm{l}$ as cut off.

As expected, TPE was the commonest cause of exudative pleural effusion (41.3\%) over all age groups. When looking at patients less than 40 years of age, the percentage of TPE rose to $63 \%$ (29/46), a pattern observed in countries with high incidence of TB. ${ }^{15,21,22}$ Fever, cough and shortness of breath were the most common symptoms occurring in $73 \%$ of the cases in agreement with other studies. ${ }^{23}$ TPEs are typically unilateral $(95 \%){ }^{24}$ In one series of 254 patients with TB pleurisy, the effusions occupied between one-third and two-thirds of the hemithorax in $46 \% .^{15}$ In our study as well, TPE was unilateral in $97.8 \%$ of the cases and there was no site predilection, and Medium sized effusion were the most common (57.8\%). The pleural fluid in TPE was predominantly lymphocytic in $62.2 \%$ of the cases and in $66.7 \%$ of the cases the pleural lymphocyte neutrophil ratio was more than 0.75 . The use of the ratio is particularly important as Burgess et al. ${ }^{25}$ have shown that Specificity is increased when the lymphocyte to neutrophil ratio is greater than 0.75 and the ADA is greater than 50 $\mathrm{U} / \mathrm{L}$. Different studies have shown that the pleural fluid protein in TPE is invariably $>3.0 \mathrm{~g} / \mathrm{dL}$ (30 $\mathrm{g} / \mathrm{L})$, and $>5.0 \mathrm{~g} / \mathrm{dL}(50 \mathrm{~g} / \mathrm{L})$ in 50 to 77 percent of cases. ${ }^{26,27}$ In our study, the pleural fluid protein was $>5 \mathrm{~g} / \mathrm{dl}$ in $37.8 \%(17 / 45)$ of the cases whereas a level of $>3 \mathrm{~g} / \mathrm{dl}$ was present in $88.9 \%(40 / 45)$ of the cases. We relied heavily on pleural fluid ADA for the diagnosis of TPE and it was >60U/l in $68.9 \%(31 / 45)$. The diagnosis was based on clinical suspicion in only 7 of the cases, positive sputum microscopy in 5 of the cases and positive gene xpert on sputum in 2 of the cases. 
Malignancy was the second most common cause of exudative pleural effusions in our study and the most frequent cause among patients older than 60 years. Others have also made the same observation. ${ }^{11}$ There were 23 cases $(21.1 \%$ ) of MPE as a result of Bronchogenic Carcinoma, whereas 3 more cases were a result of Metastatic Pleural Effusion. The differential diagnosis between TPE and MPE is a very important clinical problem. Compared to TPE, these patients were older in Age (mean age $65 \pm 13$ years) and had symptoms for longer duration of time (median duration 60 days). Fever understandably was more common in TPE than MPE, whereas chest pain was more common in the MPE group which could be due to increased number of larger size effusions as well as parietal and chest wall extension of the tumour. History of Smoking was present in $82 \%$ of the cases with MPE whereas only $11 \%$ of TPE were smokers. The Median pack years for the MPE group was 30 pack years. These clinic-demographic pictures do point to some distinction in the presentation of MPE compared to TPE. Distinction of MPE and TPE is also difficult by pleural fluid analysis. There was no significant difference in the Total Leukocyte count, pleural lymphocyte percentage, pleural glucose levels or the pleural LDH. However, interestingly, though the pleural to serum protein ratio was similar in both the groups, pleural fluid protein was $>5 \mathrm{~g} / \mathrm{dl}$ in $17(37.8 \%)$ of the patients with TPE in comparison to $1(4.3 \%)$ of MPE and this difference was significant.

Measurement of adenosine deaminase (ADA) may be helpful with a differential diagnosis of malignant versus tuberculous pleurisy when an exudative effusion is lymphocytic, but initial cytology and smear and culture for tuberculosis are negative. ${ }^{16,17,28}$ Specificity is increased when the lymphocyte to neutrophil ratio is greater than 0.75 and the ADA is greater than $50 \mathrm{U} / \mathrm{L} .{ }^{25}$ False negatives and positive ADA results do occur, so ADA results need to be considered in the context of other features of the patient's clinical presentation.

In our study, the ADA values in TPE and MPE were discriminatory. The median ADA in TPE was $90 \mathrm{U} / \mathrm{l}$ whereas it was $40 \mathrm{U} / \mathrm{l}$ in the MPE subset. However, $5 / 23(21.7 \%)$ of the patient with MPE also had values more than $60 \mathrm{U} / \mathrm{l}$, interestingly in all 5 of these cases the pleural fluid protein was $<5 \mathrm{~g} /$ $\mathrm{dl}$, which is a very interesting observation and will be interesting to see if it is replicated in our future studies. Pleural fluid lymphocyte neutrophil ratio though higher in the TPE group was not statistically significant, however there was a trend towards a difference as the p-value was .096.

Parapneumonic effusions together with empyema thoracis accounted for $26.6 \%$ of all our cases. It is estimated that about $40 \%$ of patients with pneumonia develop a concomitant pleural effusion ${ }^{30}$ although some studies show the incidence of this complication of pneumonia to be less than $20 \%{ }^{31}$ Compared to TPE, duration of symptoms at presentation was shorter (median duration 8 days in PPE to 30 days in TPE) which is expected as PPE has more acute presentation whereas TPE is acute or sub-acute in onset. However, these patients were hospitalized longer (median duration 10 days to 6 for TPE), and thoracostomy had to be performed in $44 \%$ of these cases. The complicated nature, the need to complete antibiotic course and the complications related to thoracostomy might have led to the longer duration of stay. The size of the effusion was large in only 1 case and majority of them were small $(65.5 \%)$ and medium in size (31\%).

There were quite a few discriminating factors in the pleural fluid analysis. The pleural neutrophils were more in the PPE subset and the pleural lymphocytes less, consequently, the pleural lymphocyte neutrophil ratio was 0.17 in the PPE group and 2.33 in the TPE group.

Pleural fluid glucose was lower in the PPE group however the difference was not statistically significant. Pleural ADA was again discriminatory, with median values of $31 \mathrm{U} / \mathrm{l}$ in the PPE subset compared to $90 \mathrm{U} / \mathrm{l}$ in the TPE subset.

\section{CONCLUSION}

Thus, using the clinical characteristics and basic lab investigations, features such as increased age, increased duration of symptom, lack of fever, positive Smoking history, lower ADA levels and a lower pleural protein of $<5 \mathrm{~g} / \mathrm{dl}$ pointed more towards MPE than TPE. Similarly, decreased duration of symptoms, smaller size of effusion, a higher pleural neutrophil percentage, a lower pleural lymphocyte percentage, a lower pleural lymphocyte to neutrophil ratio and a lower ADAwere more in favour of PPE than TPE. The appreciation of these characteristic can aid in the differentiation 
of Tuberculous from Non-tuberculous causes of exudative pleural effusion and thus improve the clinical decision making in resource limited setting.

\section{REFERENCES}

1. Chetty KG. Transudative pleural effusions. Clin Chest Med.1985;6:49-54.

2. Light RW. Diagnostic principles in pleural disease. Eur Respir J.1997;10:476-81.

3. Storey DD, Dines DE, Coles DT. Pleural effusion: a diagnostic dilemma. Journal of the American Medical Association,1976;236:2183-6.

4. Gannels JJ. Perplexing pleural effusion. Chest.1978;47:390-3.

5. Keshmiri M, Hashemzadeh M. Use of cholesterol in differentiating of exudative and transudative pleural effusions. Medical journal of the Islamic Republic of Iran. 1997; 2(3):187-9.

6. Kalaajieh WK. Etiology of exudative pleural effusion in adults in north Lebanon. Canadian respiratory journal. 2001; 8(2):93-7.

7. Liam CK, Lim KH, Wong CM. Causes of pleural exudates in a region with a high incidence of tuberculosis. Respirology.2000;5:33-8.

8. Nepal. Ministry of Health \& Population. Department of Health Services, Annual Report 2069/70 (2012/2013).

9. Baumann MH, Nolan R, Petrini M, Lee YC, Light RW,Schneider E (2007) Pleural tuberculosis in the United States incidence and drug resistance. Chest 131:1125-1132.

10. Situacio' epidemiolo'gica i tende'ncia de l'e'nde'mia tuberculosa a Catalunya [Epidemiology and trend of tuberculous endemia in Catalonia]. Departament de Salut, Generalitat de Catalunya, InformeAnual, Barcelona (2006).

11. Valde's L, Alvarez D, Valle JM, Pose A, San Jose' $E$ (1996) The etiology of pleural effusions in an area with high incidence of tuberculosis. Chest 109:158-162.

12. Light RW. Clinical practice pleural effusion. N Engl J Med. 2002;346(25):1971-7.

13. Light RW. Pleural Disease, 2nd edn. Lea \& Febiger, Philadelphia, 1992, 42.

14. Sahn SA. State of the art: the pleura. Am Rev Respir Dis 1988;138:184-234.
15. Valdés L, Alvarez D, San José E, et al. Tuberculous pleurisy: a study of 254 patients. Arch Intern Med 1998; 158:2017. 16. Piras MA, Gakis C, Budroni $M$, Andreoni $G$. Adenosine deaminase activity in pleural effusions: an aid to differential diagnosis. $\mathrm{Br}$ Med J 1978;2:1751.

17. Riantawan $P$, Chaowalit $P$, Wongsangiem $M$, Rojanaraweewong P. Diagnostic value of pleural fluid adenosine deaminase in tuberculous pleuritis with reference to HIV coinfection and a Bayesian analysis. Chest 1999;116:97.

18. Ocaña I, Martinez-Vazquez JM, Segura RM, et al. Adenosine deaminase in pleural fluids. Test for diagnosis of tuberculous pleural effusion. Chest 1983; 84:51.

19. Valdés L, San José E, Alvarez D, et al. Diagnosis of tuberculous pleurisy using the biologic parameters adenosine deaminase, lysozyme, and interferon gamma. Chest 1993;103:458.

20. Jiménez Castro D, Díaz Nuevo G, Pérez-Rodríguez E, Light RW. Diagnostic value of adenosine deaminase in nontuberculous lymphocytic pleural effusions. Eur Respir J 2003;21:220.

21. Ibrahim WH, Ghadban W, Khinji A, Yasin R, Soub H, Al-Khal AL, Bener A (2005) Does pleural tuberculosis disease pattern differ among developed and developing countries? Respir Med 99:1038-1045.

22. Porcel JM, Alema'n C, Bielsa S, Sarrapio J, Ferna'ndez de Sevilla T, Esquerda A (2008) A decision tree for differentiating tuberculous from malignant pleural effusions. Respir Med 102:11591164.

23. Pe'rez-Rodriguez E, Light RW (2008) Effusions from infections:tuberculosis. In: Light RW, Gary Lee YC (eds) Textbook of pleural diseases, 2nd edn. Hodder Arnold, London, pp 367-378.

24. Cases Viedma E, Lorenzo Dus MJ, Gonza'lezMolina A, Sanchis Alda's JL. A study of loculated tuberculous pleural effusions treated with intrapleural urokinase. Respir Med (2006);100:2037-42.

25. Burgess LJ, Maritz FJ, Le Roux I, Taljaard JJ. Combined use of pleural adenosine deaminase with lymphocyte/neutrophil ratio. Increased specificity for the diagnosis of tuberculous pleuritis. Chest 1996;109:414.

26. Berger HW, Mejia E. Tuberculous pleurisy. Chest 1973; 63:88. 
27. Epstein DM, Kline LR, Albelda SM, Miller WT. Tuberculous pleural effusions. Chest 1987; 91:106.

28. Liang QL, Shi HZ, Wang K, etal. Diagnosticaccuracy of adenosine deaminase in tuberculous pleurisy: a meta-analysis. Respir Med 2008;102:744.

29. Ogata $Y$, Aoe $K$, Hiraki $A$, et al. Is adenosine deaminase in pleural fluid a useful marker for differentiating tuberculosis from lung cancer or mesothelioma in Japan, a country with intermediate incidence of tuberculosis? Acta Med Okayama 2011;65:259.
30. Hamm H, Light RW. Parapneumonic effusion and empyema. Eur. Respir. J. 1997;10:1150-6.

31. Sow O, Frechet M, Diallo AA et al. Community acquired pneumonia in adults: a study comparing clinical features and outcome in Africa (Republic of Guinea) and Europe (France). Thorax 1996;51:385-8. 